УДК 373.016: 796(477)

doi: 10.15330/fcult.36.26-38

Олександр Корсак, Олександр Лемак, Ірина Султанова, Ірина Іванишин

\title{
ФУНКЦІОНАЛЬНИЙ СТАН І ФІЗИЧНА ПІДГОТОВЛЕНІСТЬ УЧНІВ ЛІЦЕЮ 3 ПОСИЛЕНОЮ ФІЗИЧНОЮ ПІДГОТОВКОЮ З РІЗНИМ РІВНЕМ БІОЛОГІЧНОГО РОЗВИТКУ
}

\begin{abstract}
Мета - дослідити взаємозв'язок між функиіональним станом і фізичною підготовленістю учнів з різним рівнем біологічного розвитку. Методи дослідження: 1) тестування фізичної підготовленості (комбінований силовий тест, біг на 100 і 1000 м, човниковий біг $4 \times 9$ м, стрибок у довжсиу з місия, нахил тулуба вперед з положення сидячи, підтягування з вису); 2) біологічні методи (антропометрія, визначення рівня біологічного розвитку, артеріального тиску, адаптачійного потенціалу, індексів Робінсона та Кердо, життєвого індексу, проби Штанге та Генчі); 3) методи математичної статистики. В дослідженні взяли участь 332 учні Прикарпатського лічеюю з посиленою фізичною підготовкою віком 13-17 років. Результати. Із збільшенням рівня біологічного розвитку знижуються функціональні резерви організму, про що свідчить низький показник жсттеввого індексу та індексу Робінсона. Ці зміни супроводжувалися зростанням систолічного артеріального тиску та адаптаційного потенціалу, щзо свідчить про напругу регуляторних систем організму. Із збільшенням рівня біологічного розвитку підвищуються показники комплексної силової вправи, стрибка у довжину з місия, гнучкості та підтягування у висі. Поряд з изим відбувається зниження витривалості та спритності по відношенню до підлітків з низьким рівнем біологічного розвитку. Висновок. Підвищення рівня біологічного розвитку супроводжсуться зростанням розвитку силових та швидкісно-силових якостей, а також гнучкості. Натомість, у період інтенсивного статевого дозрівання, на фоні уповільнення процесів диференціації кардіореспіраторної системи $i$ зростання напруги механізмів нейрогуморальної регуляиії функцій організму, уповільнюється зростання аеробних можливостей (витривалості). Розвиток фізичних здібностей та функиіональних резервів фізіологічних систем відбувається гетерохронно, щзо обумовлено різними темпами росту організму та біологічного розвитку. Урахування виявлених особливостей фізичного та функціонального стану організму підлітків з різним рівнем біологічного розвитку в процесі фізичної підготовки дозволить більш ефективно здійснювати дозування фізичних навантажень у підлітковому вічі.
\end{abstract}

Ключові слова: функціональний стан, підлітки, біологічний розвиток, фізична підготовленість, фізичні якості, функціональні резерви.

Purpose - to investigate the relation between the functional state and the physical fitness of students with different levels of biological development. Methods of the Research. 1) Physical fitness tests (combined force test, 100 and $1000 \mathrm{~m}$ running, $4 \times 9 \mathrm{~m}$ multi-stage fitness test, standing long jump, body leaning forward from seated position, pull-up on the beam); 2) Biological methods (anthropometry, determination of the level of biological development, blood pressure, adaptive capacity, Robinson and Kerdo indixes, life index, Shtange and Genchi's tests; 3) methods of mathematical statistics. The study involved 332 pupils of the Carpathian Lyceum with enhanced physical training between the ages of 13 and 17. Results. As the level of biological development increases, the functional reserves of the organism decrease, as shown by the low life index and the Robinson index. These changes were accompanied by an increase in systolic blood pressure and adaptive capacity, indicating the stress of the organism's regulatory systems. As the level of biological development increases, so do the indicators of comprehensive strength exercise, standing long jump, flexibility and pull-up on the beam. In addition, the stamina and agility of adolescents with low levels of biological development are decreasing. Conclusion. The increase in the level of biological development is accompanied by a growth in the development of force and speed-force qualities, as well as flexibility. However, during the period of intense puberty, against the background of the slowing of the differentiation of the cardiorespiratory fitness and the increase in the tension of the mechanisms of neuro-humoral regulation of body functions, the growth of aerobic possibilities (stamina) is slowed down. The development of physical abilities and functional reserves of physiological systems is heterochronous, due to the different growth rates of the organism and biological development. Taking into account the identified physical and functional conditions of adolescents with different levels of biological development in the course of physical training will make it possible to carry out more effective dosing of physical loads in adolescence.

Keywords: functional state, adolescents,biological development, physical-fitness, physical qualities, functional reserves.

(C) Корсак О., Лемак О., Султанова I.,

Іванишин I., 2020 
Постановка проблеми й аналіз результатів останніх досліджень. Стан провідних функціональних систем організму в процесі його росту та формування визначає не тільки резерви здоров'я індивіда, але і лежить в основі прояву певних фізичних якостей та обумовлює особливості дозування фізичних навантажень. Наше сьогодення характеризується недостатніми функціональними можливостями організму дітей та підлітків $[1,10,15]$ та низьким рівнем розвитку фізичних якостей $[6,10,12]$. Особливої уваги заслуговує період статевого дозрівання, коли порушується нейрогуморальний баланс організму, що спричинює певну напругу регуляторних систем. Відомо, що високі темпи біологічного розвитку обмежують функціональні можливості організму в період його росту та формування [3, 14]. Особливої уваги потребують підлітки, що мають в цей період регулярні інтенсивні фізичні навантаження. Одним з найпоширенішим підходом у дозуванні фізичних навантажень $\epsilon$ ступінь розвитку фізичних якостей. Проте високий рівень фізичної підготовленості може поєднуватися із значною напругою провідних адаптаційних систем організму, що є лімітуючим фактором щодо обсягу фізичних навантажень. Тому дослідження функціонального стану та фізичної підготовленості підлітків з різним рівнем біологічного розвитку є актуальним питанням сьогодення, що має важливе практичне значення.

Мета дослідження - дослідити взаємозв'язок між функціональним станом і фізичною підготовленістю учнів з різним рівнем біологічного розвитку.

Методи дослідження. Під час дослідження використовували наступні методи: 1) контент-аналіз науково-методичної літератури; 2) тестування фізичної підготовленості (за 7-ма тестами: комбінований силовий тест, біг на 100 м, 1000 м, човниковий біг $4 \times 9$ м, стрибок у довжину з місця, нахил тулуба вперед з положення сидячи, підтягування у висі) $[2,16]$; 3) біологічні методи (антропометрію, визначення артеріального тиску, адаптаційного потенціалу, індексів Робінсона та Кердо, життєвого індекса (ЖІ), проби Штанге та Генчі; визначення рівня біологічного розвитку) [9]; 4) методи математичної статистики [13].

В педагогічному експерименті приймали участь 332 учні Прикарпатського ліцею 3 посиленою фізичною підготовкою віком 13-17 років. Розподіл контингенту за біологічним розвитком показаний на рис. 1.

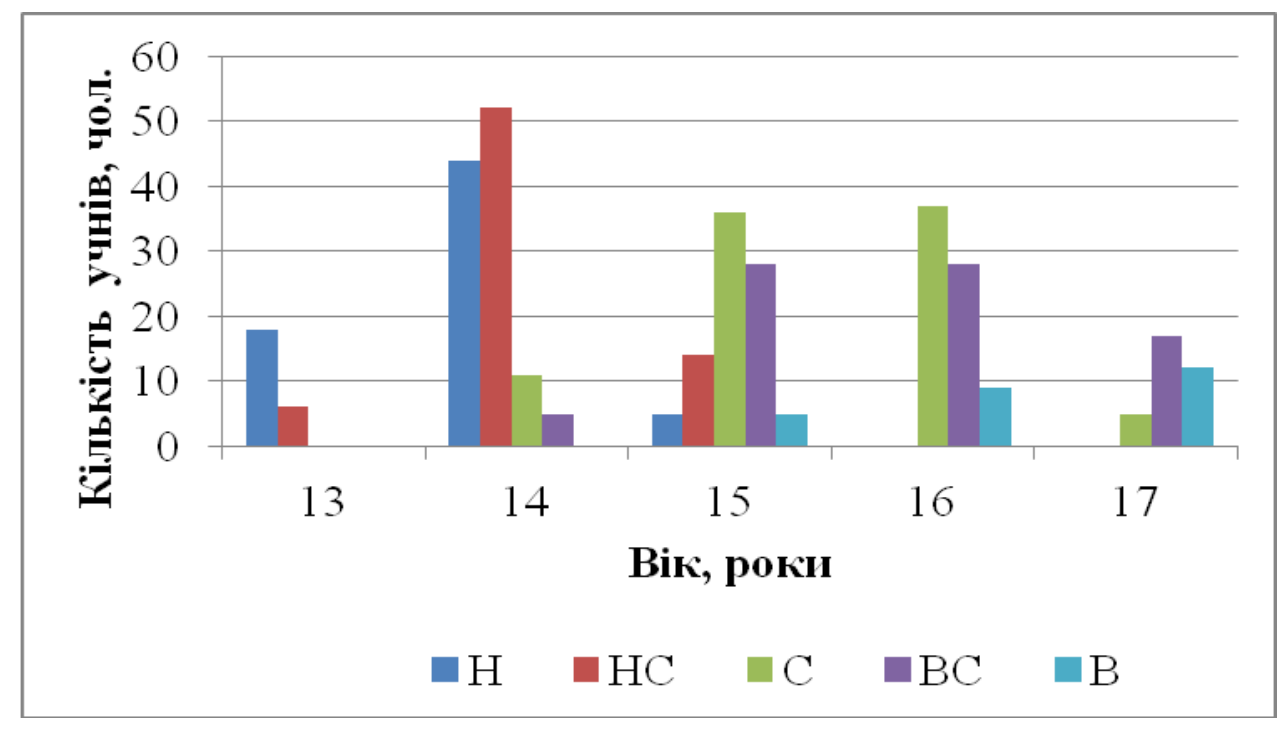

Puc. 1. Розподіл учасників дослідження за віком та рівнями біологічного розвитку: н - низький; нс - нижче середнього - середній; вс - вище середнього; в - високий (аналогічно на всіх інших рисунках). 
Результати дослідження. В результаті аналізу отриманих даних функціонального стану дихальної системи підлітків виявлено низку особливостей (табл. 1). В групі з високим рівнем біологічного розвитку (БР) у 15-ти річних ліцеїстів виявлено достовірно нижчі показники життєвого індекса у порівнянні із показниками груп 3 нижче середнім, середнім та вище середнім рівнем БР. Життєвий індекс в групі з високим рівнем БР був низьким. Результати проби Штанге у 14 років були вищими в групі 3 середнім та вище середнім рівнем БР у порівнянні із показниками груп із низьким та нижче за середній рівень БР. Однак, в групі з високим рівнем БР проявлялася тенденція до зниження часу затримки дихання на вдиху у порівнянні із показниками груп 3 середнім та вище середнього рівнями БР.

Вікова динаміка функціонального стану дихальної системи учнів

Таблиия 1 3 різним рівнем біологічного розвитку

\begin{tabular}{|c|c|c|c|c|c|c|}
\hline \multirow[t]{2}{*}{ Показник } & \multirow{2}{*}{$\begin{array}{l}\text { Вік, } \\
\text { роки }\end{array}$} & \multicolumn{5}{|c|}{ Рівень біологічного розвитку } \\
\hline & & низький & $\begin{array}{c}\text { нижче } \\
\text { середнього }\end{array}$ & середній & $\begin{array}{c}\text { вище } \\
\text { середнього }\end{array}$ & високий \\
\hline \multirow{5}{*}{$\begin{array}{l}\text { Життєви } \\
\text { й індекс, } \\
\text { ум.од. }\end{array}$} & 13 & $53,45 \pm 2,34$ & $46,34 \pm 3,17$ & - & - & - \\
\hline & 14 & $53,04 \pm 1,22$ & $51,43 \pm 1,46$ & $51,37 \pm 1,68$ & $50,56 \pm 2,38$ & - \\
\hline & 15 & $48,94 \pm 2,35$ & $50,83 \pm 2,14$ & $51,70 \pm 1,02$ & $52,52 \pm 1,21$ & $43,01 \pm 1,44 \bullet \Delta \bullet$ \\
\hline & 16 & - & - & $50,77 \pm 1,33$ & $52,76 \pm 1,27$ & $48,57 \pm 1,66$ घ \\
\hline & 17 & - & - & $50,15 \pm 2,39$ & $46,94 \pm 1,68 \boldsymbol{\square}$ & $49,42 \pm 1,55 \mathbf{\square}$ \\
\hline \multirow{5}{*}{$\begin{array}{l}\text { Проба } \\
\text { Штанге, } \\
\text { с }\end{array}$} & 13 & $50,22 \pm 3,81$ & $50,33 \pm 4,76$ & - & - & - \\
\hline & 14 & $55,45 \pm 2,97$ & $57,15 \pm 2,92$ & $56,42 \pm 5,12$ & $62,50 \pm 2,50$ & - \\
\hline & 15 & $59,67 \pm 7,75$ & $50,14 \pm 3,82$ & $62,31 \pm 4,13$ • & $68,19 \pm 4,42$ & $42,00 \pm 2,02 \Delta \bullet$ \\
\hline & 16 & - & - & $50,47 \pm 2,97$ [ & $51,60 \pm 3,79 \boldsymbol{\Delta} \square$ & $41,11 \pm 5,17$ \\
\hline & 17 & - & - & $65,00 \pm 2,00$ & $55,35 \pm 4,76$ & $56,33 \pm 7,03$ \\
\hline \multirow{5}{*}{$\begin{array}{l}\text { Проба } \\
\text { Генче, с }\end{array}$} & 13 & $25,06 \pm 2,40$ & $35,77 \pm 7,51$ & - & - & - \\
\hline & 14 & $26,90 \pm 1,65$ & $23,78 \pm 1,51$ & $26,67 \pm 2,72$ & $38,00 \pm 5,03 *$ & - \\
\hline & 15 & $31,67 \pm 8,99$ & $21,71 \pm 1,83$ & $26,34 \pm 1,88$ & $28,72 \pm 1,96$ & $21,00 \pm 4,60$ \\
\hline & 16 & - & - & $28,68 \pm 2,04$ & $29,72 \pm 1,33$ & $32,22 \pm 2,15 \mathbf{\square}$ \\
\hline & 17 & - & - & $26,60 \pm 2,00$ & $28,29 \pm 1,52$ & $32,42 \pm 1,69 \Delta \boldsymbol{m}$ \\
\hline
\end{tabular}

Примітки: 1) Достовірні відмінності $(\mathrm{P}<0,05)$ позначено * - у порівнянні із показниками групи 3 низьким рівнем біологічного розвитку; - у порівнянні із показниками групи з нижче середнього рівнем біологічного розвитку; $\Delta-$ у порівнянні із показниками групи з середнім рівнем біологічного розвитку; • - у порівнянні із показниками групи з вище середнього рівня біологічного розвитку. 2) Достовірні відмінності $(\mathrm{P}<0,05)$ позначено у порівнянні із показниками: $\square-$ у 13 років; $\boldsymbol{\Lambda}$ - у 14 років; - у 15 років.

Найвищі показники проби Генче виявлені в групі з вище середнім рівнем БР у 14 років. Також в групі з високим рівнем БР зареєстровані вірогідно вищі показники вказаної проби у 16 та 17 років у порівнянні із значенням у 15 років $(\mathrm{P}<0,05)$.

В учнів з низьким та нижче середнього рівнем біологічного розвитку у 14 років виявлено достовірне зниження систолічного артеріального тиску порівняно із показниками у 13 років (табл. 2). В групі з середнім та вище за середній рівні БР у 14 років систолічний артеріальний тиск перевищував показники групи 3 низьким рівнем БР. В групі з високим рівнем БР систолічний артеріальний тиск перевищував показники групи з середнім рівнем БР у 15-17 років. Також у 15 та 16 років в групі з високим рівнем БР систолічний артеріальний тиск був вищий у порівнянні із групою з вище за середній рівень БР. 
Корсак Олександр, Лемак Олександр, Султанова Ірина, Іванишин Ірина. Функціональний стан і фізична ...

Таблиия 2

Вікова динаміка функціонального стану серцево-судинної та регуляторних систем організму учнів з різним рівнем біологічного розвитку

\begin{tabular}{|c|c|c|c|c|c|c|}
\hline \multirow[t]{2}{*}{ Показник } & \multirow{2}{*}{$\begin{array}{l}\text { Вік, } \\
\text { роки }\end{array}$} & \multicolumn{5}{|c|}{ Рівень біологічного розвитку } \\
\hline & & низький & $\begin{array}{c}\text { нижче } \\
\text { середнього }\end{array}$ & середній & $\begin{array}{c}\text { вище } \\
\text { середнього }\end{array}$ & високий \\
\hline \multirow{5}{*}{$\begin{array}{l}\text { АТс, } \\
\text { мм рт. ст. }\end{array}$} & 13 & $110,33 \pm 2,85$ & $115,83 \pm 4,40$ & - & - & - \\
\hline & 14 & $101,30 \pm 2,03 \square$ & $105,79 \pm 1,83$ ㅁ & $111,06 \pm 3,86^{*}$ & $117,00 \pm 3,00^{*}$ & - \\
\hline & 15 & $110,00 \pm 9,29$ & $108,79 \pm 3,59$ & $111,94 \pm 1,81$ & $115,96 \pm 2,21$ & $126,00 \pm 1,01 \vee \Delta \bullet$ \\
\hline & 16 & - & - & $112,73 \pm 1,76$ & $117,36 \pm 2,34$ & $127,11 \pm 2,82 \Delta \bullet$ \\
\hline & 17 & - & - & $113,00 \pm 3,00$ & $116,94 \pm 2,37$ & $122,67 \pm 3,04 \Delta$ \\
\hline \multirow{5}{*}{$\begin{array}{l}\text { Індекс } \\
\text { Робінсона, } \\
\text { ум.од. }\end{array}$} & 13 & $79,66 \pm 3,66$ & $94,89 \pm 6,36^{*}$ & - & - & - \\
\hline & 14 & $73,52 \pm 2,10$ & $78,51 \pm 1,89 \square$ & $74,59 \pm 3,71$ & $88,80 \pm 2,40 * \Delta$ & - \\
\hline & 15 & $84,19 \pm 7,78$ & $77,16 \pm 2,72 \square$ & $80,17 \pm 1,77$ & $81,37 \pm 2,89$ & $93,87 \pm 11,97$ \\
\hline & 16 & - & - & $84,12 \pm 2,26 \boldsymbol{\Delta}$ & $81,25 \pm 2,37 \mathbf{\Delta}$ & $86,39 \pm 4,03$ \\
\hline & 17 & - & - & $76,26 \pm 1,46 \diamond$ & $78,00 \pm 2,60 \boldsymbol{\Delta}$ & $84,98 \pm 2,97 \Delta$ \\
\hline \multirow{5}{*}{$\begin{array}{l}\text { Індекс } \\
\text { Кердо, } \\
\text { ум.од }\end{array}$} & 13 & $11,48 \pm 2,31$ & $23,08 \pm 5,56$ & - & - & - \\
\hline & 14 & $14,10 \pm 2,93$ & $17,33 \pm 2,01$ & $10,96 \pm 5,58$ & $7,57 \pm 3,08$ & - \\
\hline & 15 & $32,45 \pm 6,89 \square \mathbf{\Delta}$ & $9,99 \pm 4,27 *$ & $8,85 \pm 3,02 *$ & $7,44 \pm 3,28^{*}$ & $0,50 \pm 6,65^{*}$ \\
\hline & 16 & - & - & $15,10 \pm 2,67$ & $5,65 \pm 3,35 \Delta$ & $-11,21 \pm 5,91$ \\
\hline & 17 & - & - & $-3,71 \pm 0,77 \mathbf{\Delta} \mathbf{v} \diamond$ & $-0,15 \pm 3,04$ & $-0,67 \pm 5,05$ \\
\hline \multirow{5}{*}{$\begin{array}{l}\text { Адаптацій } \\
\text { ний } \\
\text { потенціал, } \\
\text { ум.од. }\end{array}$} & 13 & $1,75 \pm 0,68$ & $1,97 \pm 0,09$ & - & - & - \\
\hline & 14 & $1,62 \pm 0,04$ & $1,71 \pm 0,04 \square$ & $1,70 \pm 0,07$ & $1,98 \pm 0,05^{*} \triangleleft \Delta$ & - \\
\hline & 15 & $1,73 \pm 0,17$ & $1,76 \pm 0,04 \square$ & $1,81 \pm 0,03$ & $1,84 \pm 0,05$ & $2,18 \pm 0,16 \bullet \Delta$ \\
\hline & 16 & - & - & $1,86 \pm 0,04 \boldsymbol{\Delta}$ & $1,89 \pm 0,04$ & $2,12 \pm 0,05 \Delta \bullet$ \\
\hline & 17 & - & - & $1,84 \pm 0,02$ & $1,89 \pm 0,05$ & $2,06 \pm 0,06 \Delta \bullet$ \\
\hline
\end{tabular}

Примітки: 1) Достовірні відмінності $(\mathrm{P}<0,05)$ позначено * - у порівнянні із показниками групи 3 низьким рівнем біологічного розвитку; - у порівнянні із показниками групи з нижче середнього рівнем біологічного розвитку; $\Delta-$ у порівнянні із показниками групи з середнім рівнем біологічного розвитку; • - у порівнянні із показниками групи з вище середнього рівня біологічного розвитку. 2) Достовірні відмінності $(\mathrm{P}<0,05)$ позначено у порівнянні із показниками: - - у 13 років; $\boldsymbol{\Delta}$ - у 14 років; - - 15 років; $\diamond-$ у 16 років.

Індекс Робінсона в групі з нижче за середній рівень БР у 13 років відповідав нижче середньому рівню в той час, коли в групі з низьким рівнем БР індекс Робінсона мав середні величини.

У 14 років в групі 3 вище середнім рівнем БР індекс Робінсона був достовірно вищим у порівнянні із групами з низьким, нижче середнього та середнім рівнем, що свідчить про зниження коронарного резерву міокарда у ліцеїстів цієї групи. В групі з нижче середнім рівнем БР у 14 років відмічено достовірне підвищення коронарного резерву міокарда у порівнянні із показниками цієї групи у 13 років.

Індекс Кердо в групі 3 нижче середнім рівнем БР у 15 років достовірно перевищував значення у 13 та 14 років, що свідчить про збільшення пулу симпатичних впливів. Поряд 3 тим, у 15 років в групах з нижче середнім, середнім та вище за середній рівні БР індекс Кердо був достовірно нижчим у порівнянні із групою з низьким рівнем БР, де виявлено перевагу симпатичних впливів.

У групі з середнім рівнем БР у 17 років виявлено перевагу парасимпатичного відділу вегетативної нервової системи. 
В групі з високим рівнем БР у 14 років адаптаційний потенціал достовірно перевищував значення групи з низьким, нижче за середній та середній рівні БР, що свідчить про зростання напруги адаптаційних механізмів в цій групі.

В групі з високим рівнем БР у 15-17 років показник адаптаційного потенціалу був вищим у порівнянні із групою з середнім рівнем БР. Також у 16 та 17 років в цій групі адаптаційний потенціал був достовірно вищим у порівнянні із показниками групи 3 нижче за середній рівень БР.

В групі з нижче за середній рівень БР адаптаційний потенціал у 14 та 15 років був достовірно нижчим, ніж у 13 років.

Узагальнені результати функціонального стану серцево-судинної та дихальної системи у відповідності до рівня БР представлено в табл. 3. Як видно з даної таблиці в групі ліцеїстів з високим рівнем БР життєвий індекс знижується до низького рівня, в той час як в інших групах він відповідає нижче середньому рівню. Достовірних змін 3 боку проби Штанге не виявлено, однак показники проби Генче достовірно зростали у порівнянні із значенням в групах з низьким, нижче середнього та середнім рівнем БР на $17,8 \%(\mathrm{P}<0,05), 27,3 \%(\mathrm{P}<0,05)$ та 14,5\% ( $<<0,05)$ відповідно. Величина систолічного артеріального тиску в групі з високим рівнем БР на $19,7 \%(\mathrm{P}<0,05)$ перевищувала показники групи 3 низьким рівнем БР. Також зростав індекс Робінсона в групі з високим рівнем БР порівняно із величиною в групі з низьким рівнем на $13,9 \%(\mathrm{P}<0,05)$, що свідчить про зниження коронарного резерву.

Адаптаційний потенціал в групі з високим рівнем БР був вищим на 25,1\% $(\mathrm{P}<0,05)$, ніж значення в групі з низьким рівнем БР, що відображає наростання напруги адаптаційних механізмів.

Табличя 3

Функціональний стан учнів ліцею з різним рівнем біологічного розвитку

\begin{tabular}{|c|c|c|c|c|c|}
\hline \multirow[t]{3}{*}{ Показник } & \multicolumn{5}{|c|}{ Рівень біологічного розвитку } \\
\hline & низький & $\begin{array}{c}\text { нижче } \\
\text { середнього }\end{array}$ & середній & $\begin{array}{c}\text { вище } \\
\text { середнього }\end{array}$ & високий \\
\hline & $n=65$ & $\mathrm{n}=73$ & $\mathrm{n}=96$ & $\mathrm{n}=75$ & $n=23$ \\
\hline $\begin{array}{l}\text { Життєвий } \\
\text { індекс, ум.од. }\end{array}$ & $52,96 \pm 1,05$ & $50,59 \pm 1,18$ & $51,05 \pm 0,72$ & $51,33 \pm 0,80$ & $48,53 \pm 1,08 * \bullet$ \\
\hline $\begin{array}{l}\text { Проба Штан- } \\
\text { ге, с }\end{array}$ & $54,20 \pm 2,30$ & $55,35 \pm 2,26$ & $57,21 \pm 2,23$ & $58,96 \pm 2,55$ & $49,13 \pm 4,39$ \\
\hline $\begin{array}{l}\text { Проба Генче, } \\
\text { с }\end{array}$ & $26,61 \pm 1,35$ & $24,63 \pm 1,35$ & $27,39 \pm 1,16$ & $29,25 \pm 0,96$ & $31,35 \pm 1,39 * \Delta$ \\
\hline $\begin{array}{l}\text { AТc, } \\
\text { мм рт. ст. }\end{array}$ & $104,20 \pm 1,69$ & $106,88 \pm 1,57$ & $112,14 \pm 1,17^{*}$ & $116,73 \pm 1,30 * \Delta$ & $124,70 \pm 1,94 * \Delta \bullet$ \\
\hline $\begin{array}{l}\text { Індекс Робін- } \\
\text { сона, ум.од. }\end{array}$ & $75,72 \pm 1,80$ & $79,43 \pm 1,62$ & $80,88 \pm 1,32 *$ & $80,77 \pm 1,47^{*}$ & $86,30 \pm 2,32 * \Delta \bullet$ \\
\hline $\begin{array}{l}\text { Індекс Кердо, } \\
\text { ум.од. }\end{array}$ & $14,22 \pm 2,15$ & $16,77 \pm 1,78$ & $11,81 \pm 1,85$ & $5,10 \pm 1,63 *$ & $-4,69 \pm 3,61 * \bullet$ \\
\hline $\begin{array}{l}\text { Адаптаційний } \\
\text { потенціал, } \\
\text { ум.од. }\end{array}$ & $1,67 \pm 0,03$ & $1,74 \pm 0,03$ & $1,81 \pm 0,02 * \downarrow$ & $1,87 \pm 0,03 *$ & $2,09 \pm 0,04 * \Delta \bullet$ \\
\hline
\end{tabular}

Примітки: Достовірні відмінності $(\mathrm{P}<0,05)$ позначено * - у порівнянні із показниками групи 3 низьким рівнем біологічного розвитку; - у порівнянні із показниками групи з нижче середнього рівнем біологічного розвитку; $\Delta-$ у порівнянні із показниками групи з середнім рівнем біологічного розвитку; • - у порівнянні із показниками групи з вище середнього рівня біологічного розвитку. 
Отже, із збільшенням рівня біологічного розвитку зростають показники систолічного артеріального тиску, проте не в усіх досліджуваних групах ці зміни були одно направлені. Зростання індексу Робінсона та адаптаційного потенціалу свідчить про наявну напругу регуляторних механізмів та зниження функціональних резервів міокарда.

Результати щодо фізичної підготовленості наведені на рис. 2-8. Як видно 3 рис. 2 протягом досліджуваного вікового періоду результати комплексної силової вправи (КСВ) підвищуються в усіх досліджуваних групах. Так, в групі з низьким рівнем БР у 15 років показники комплексної силової вправи перевищували результати у 14 років на $27,3 \%(\mathrm{P}<0,05)$. В групі з нижче середнім рівнем БР у 15 років результати здачі КСВ були вищі за показники у 13 років на 30,3\% (P<0,05). В групах з середнім та вище за середній рівень БР приріст показників спостерігався протягом усього досліджуваного вікового періоду. Поряд з цим в групі з високим рівнем БР приріст показників вказаної вправи у період $15-16$ років зріс на $35,2 \%(\mathrm{P}<0,05)$. Отже, чим вищий рівень БР, тим кращі показники комплексної силової вправи.

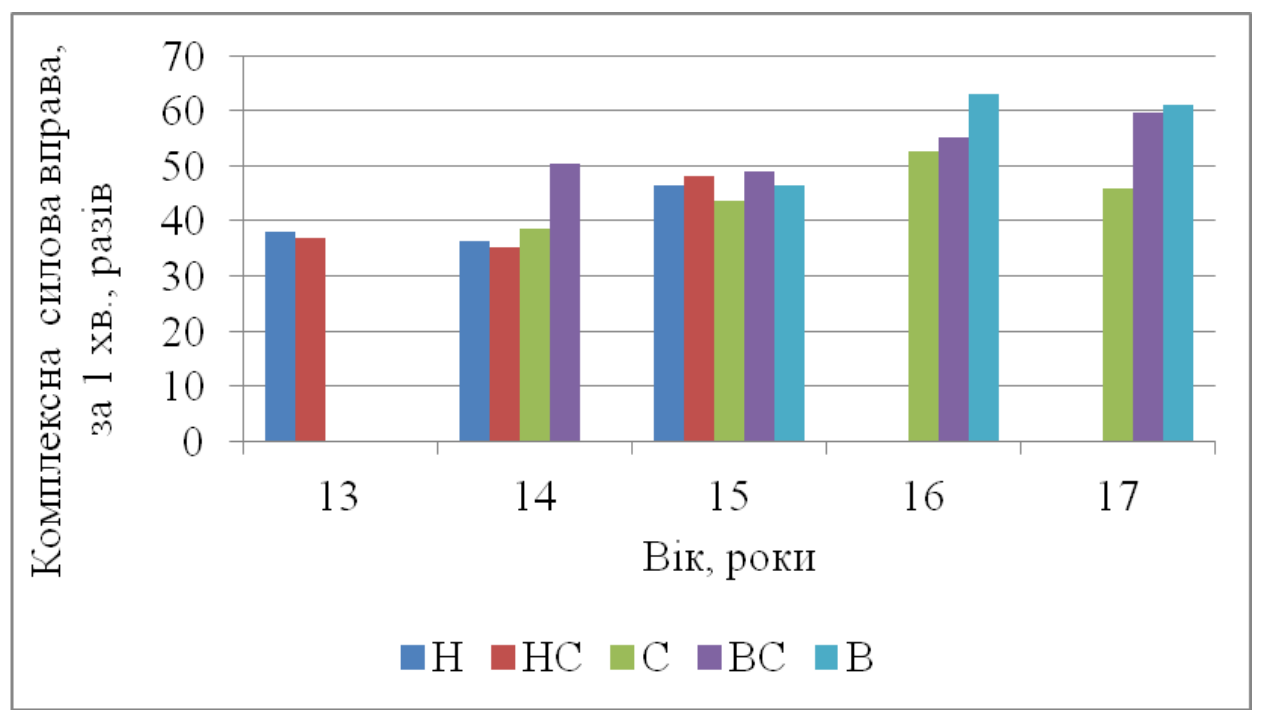

Рuc. 2. Вікова динаміка показників комплексної силової вправи у підлітків 3 різним рівнем біологічного розвитку.

Аналіз результатів в бігу на 100 м показав, що з віком є тенденція до погіршення результатів у досліджуваних групах (рис. 3). Показники групи з вище за середній рівень БР у 14 і 13 років були вищими у порівнянні із результатами групи з нижче за середній рівень БР. Встановлено приріст результатів у стрибку в довжину з місця в групах 3 низьким рівнем БР у 13-15 років та в групах 3 вище за середній та високий рівні БР у $15-17$ років (рис. 4).

Аналіз результатів човникового бігу показав, що 3 віком спритність погіршується (рис. 5). Так, в учнів з високим та вище за середній рівні БР достовірне погіршення показників спритності відбувається протягом 15-16 років.

У 13-14 років в групах з низьким та нижче за середній рівні БР знижуються показники в бігу на 1000 м (рис. 6). В групі з середнім рівнем БР у 16 років результати в бігу на 1000 м погіршувалися. Поряд з тим, у 17 років встановлено достовірне покращення цього результату по відношенню до значень у 16 років. Зниження показників в бігу на 1000 м виявлено в групі з вище середнім рівнем БР у 14-16 років та в групі 3 високим рівнем БР у 15-16 років. 


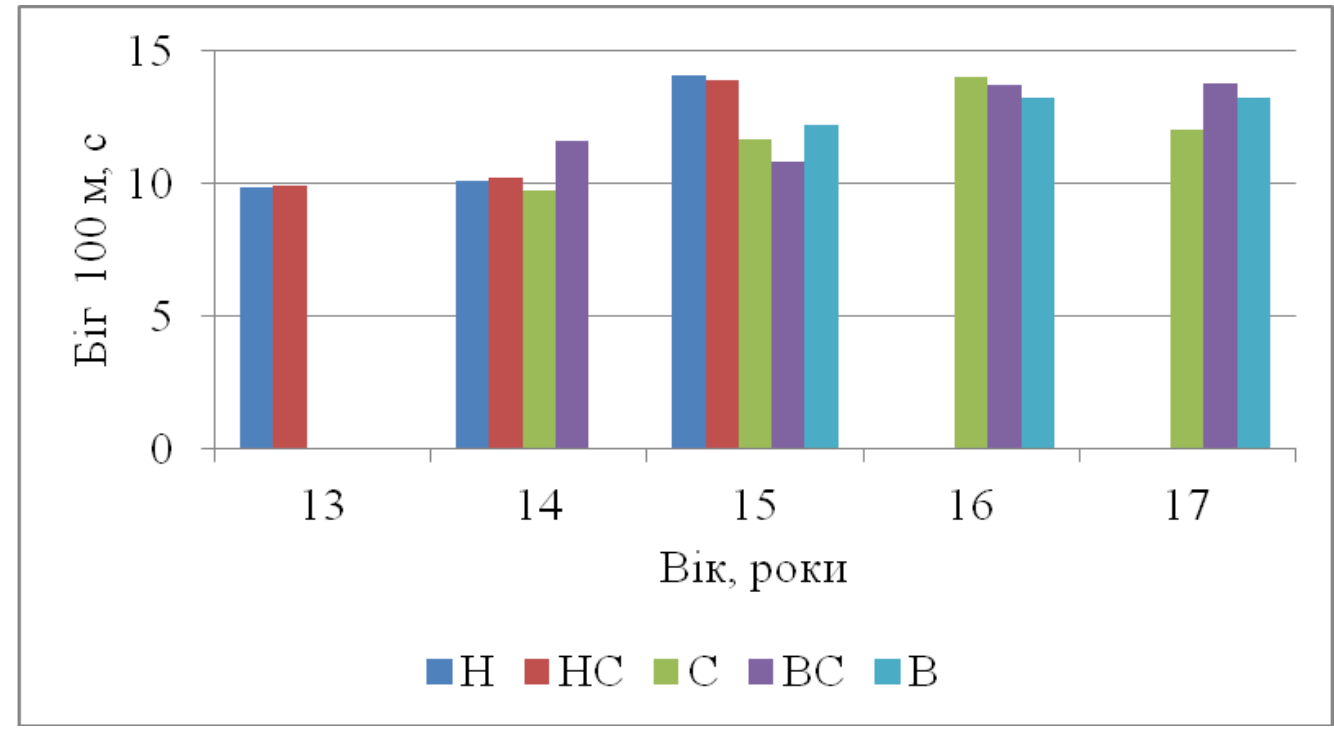

Puc. 3. Вікова динаміка показників бігу на 100 м у підлітків з різним рівнем біологічного розвитку.

Також із збільшенням рівня БР зростають показники стрибка у довжину з місця. Так, у 14 років в групі з середнім рівнем БР результати перевищували показники групи 3 низьким та нижче середнім рівнем БР на $9,1 \%(\mathrm{P}<0,05)$ та 9,3\% $(\mathrm{P}<0,05)$ відповідно. Аналогічна залежність виявлена і у 15 років. У 16 та 17 років результати стрибка у довжину 3 місця у учнів груп з високим рівнем БР були вищими ніж в групах 3 середнім та вище за середній рівні БР.

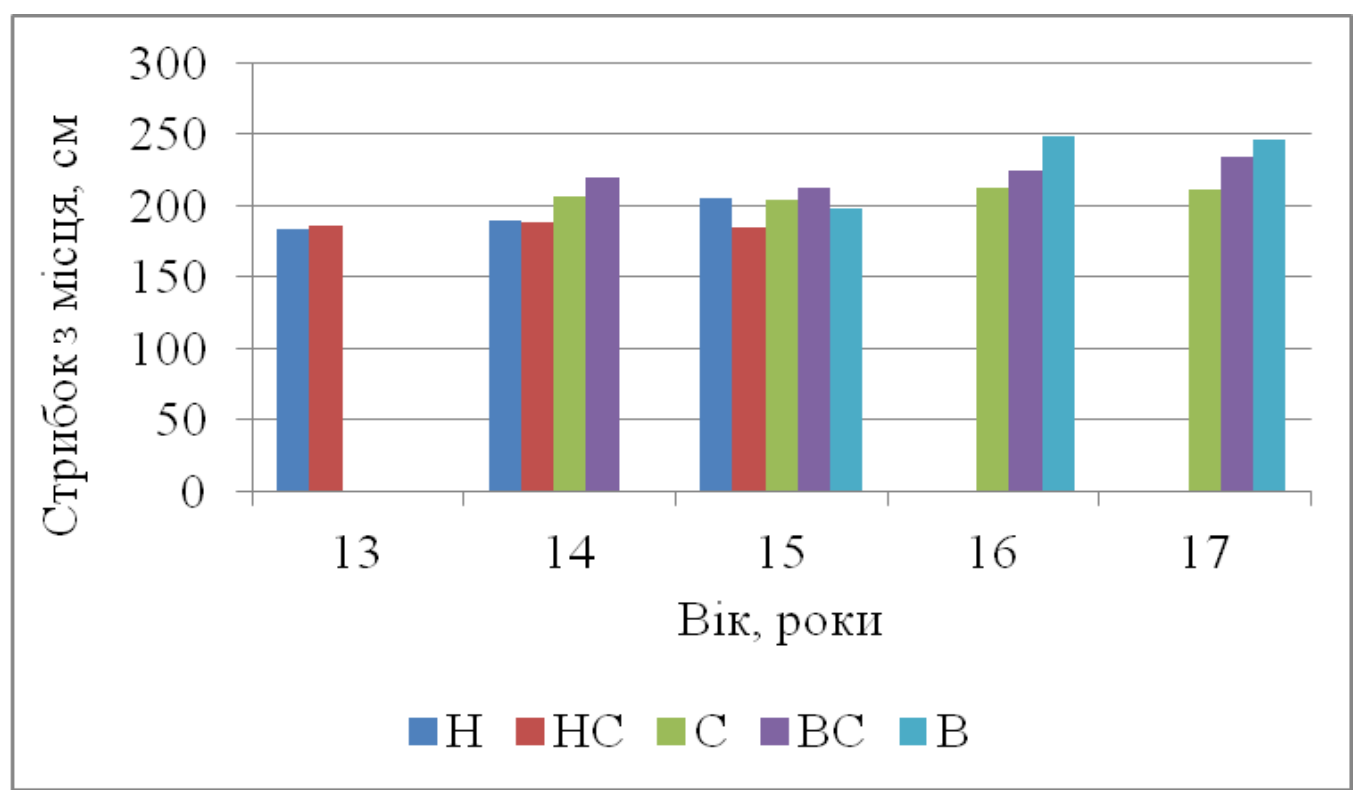

Рuc. 4. Вікова динаміка показників стрибка у довжину з місця у підлітків 3 різним рівнем біологічного розвитку.

У 14 років, в групі з вище за середній рівень БР показники в бігу на 1000 м були достовірно вищими, порівняно із показниками груп з низьким та нижче за середній рівень БР. 


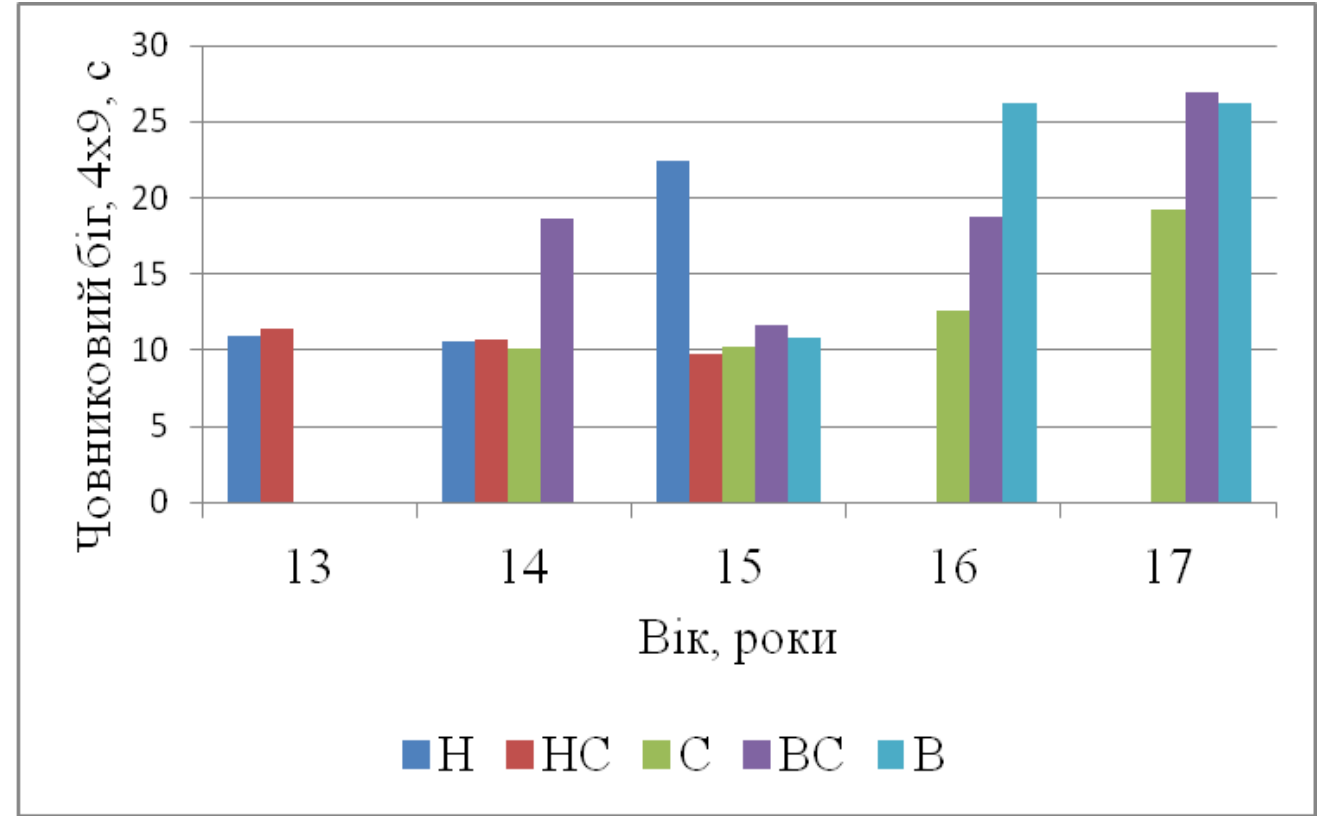

Рuc. 5. Вікова динаміка показників човникового бігу у підлітків з різним рівнем біологічного розвитку.

У 15 років показники підлітків 3 вище за середній рівень БР перевищували результати групи з середнім рівнем БР, а у 16 та 17 років результати дітей з високим рівнем БР були достовірно нижчими, порівняно із групою 3 середнім рівнем БР. Показники гнучкості у дітей з низьким рівнем БР протягом 13-15 років погіршуються на $63,8 \%(\mathrm{P}<0,05)$, а в групах з середнім та вище за середній рівень - зростають.

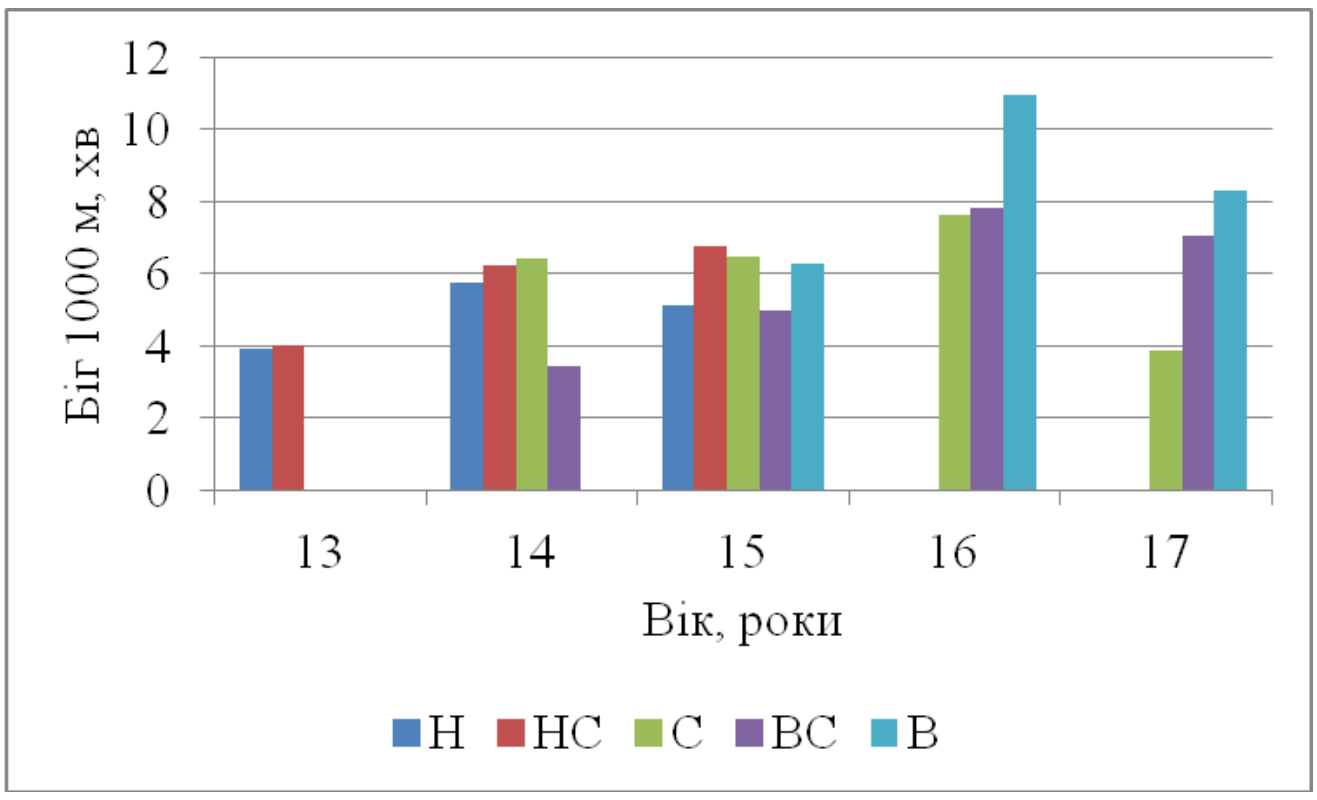

Рuc. 6. Вікова динаміка показників в бігу на 1000 м у підлітків 3 різним рівнем біологічного розвитку. 


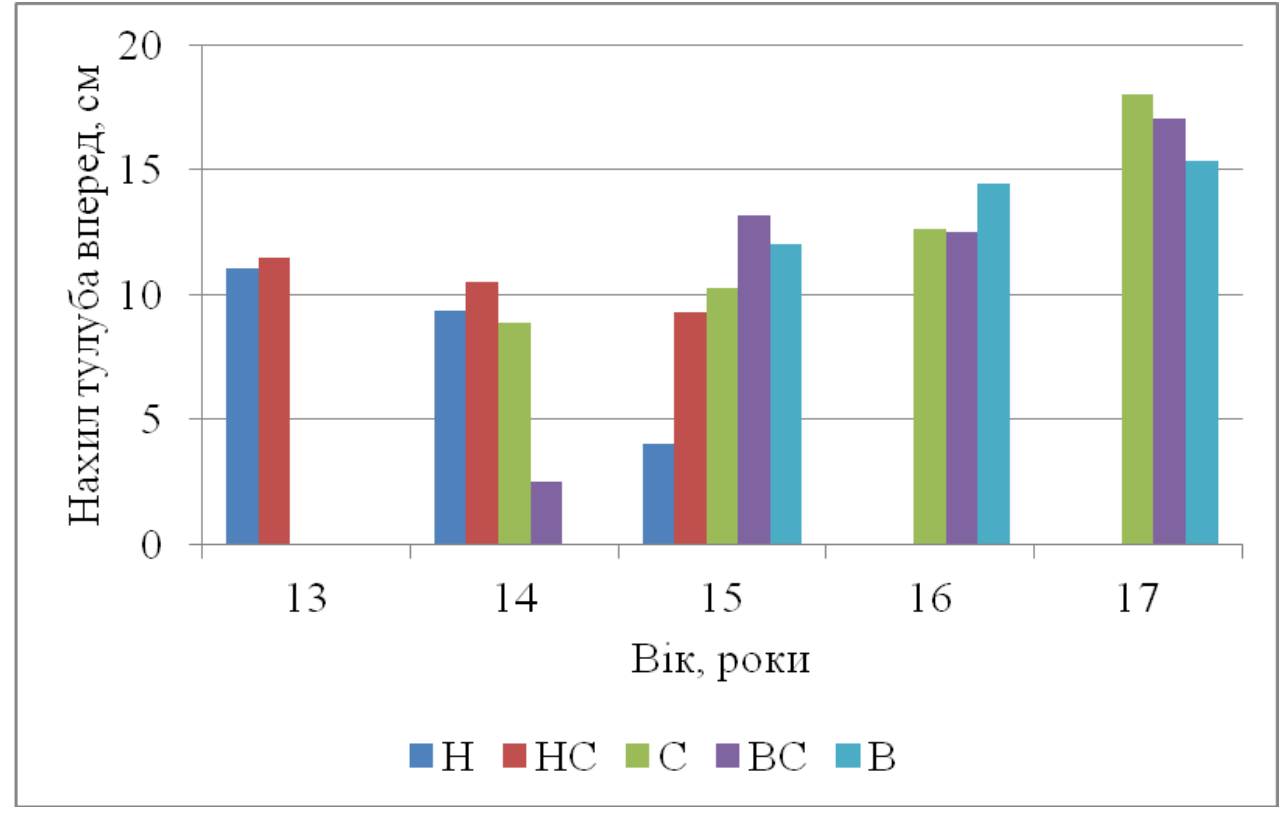

Рис. 7. Вікова динаміка показників гнучкості у підлітків з різним рівнем біологічного розвитку.

Результати підтягування з вису (рис. 8) в групах з низьким та нижче за середній рівні біологічного розвитку протягом 13-15 років зростають. В групах 3 вище за середній та високим рівнем БР виявлено зростання цих показників у 15-17 років.

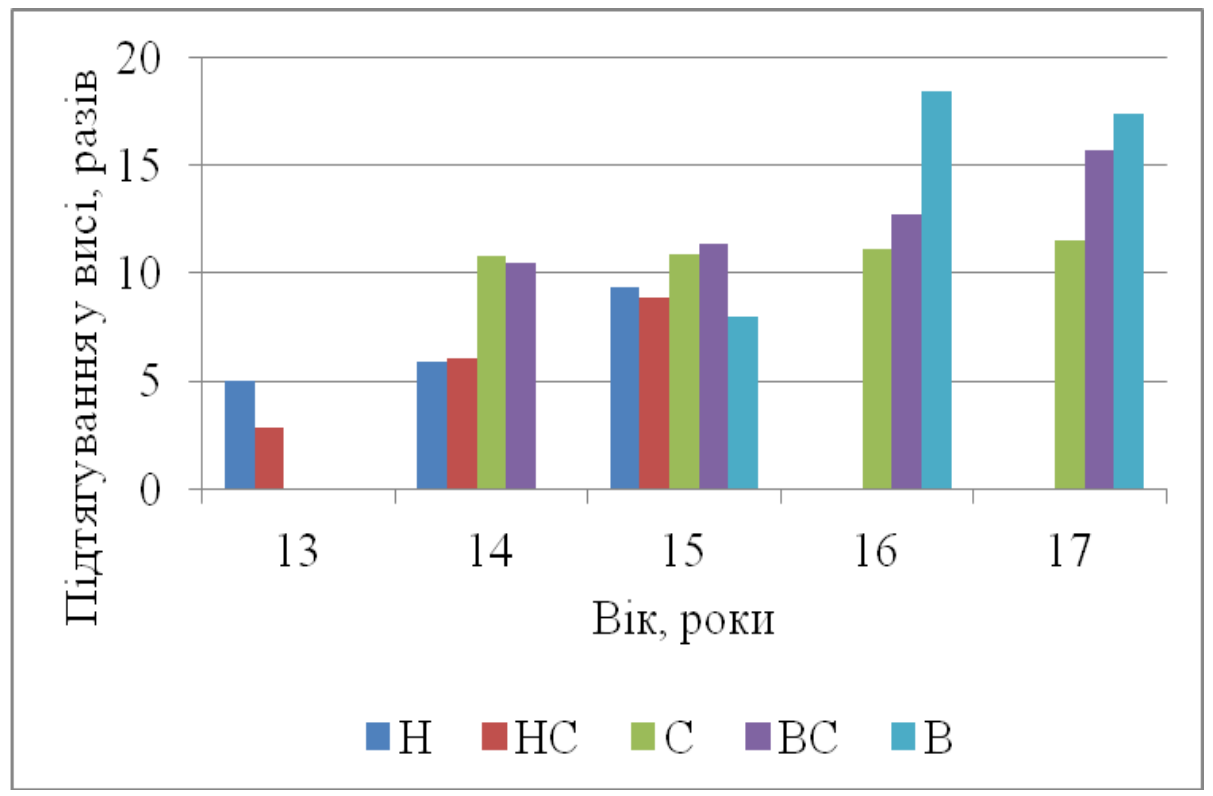

Puc. 8. Вікова динаміка показників в підтягуванні з вису у підлітків з різним рівнем біологічного розвитку.

В групі з середнім рівнем БР істотних змін у підтягуванні не встановлено. Водночас, в групі з середнім рівнем БР у 14 років результати в підтягуванні з вису перевищували аналогічні показники в групі з низьким рівнем БР на 84,6\% $(\mathrm{P}<0,05)$ та в групі з низьким рівнем - на 78,5\% ( $<<0,05)$. 
Узагальнені дані показників фізичної підготовленості з різним рівнем біологічного розвитку представлено у табл. 4. Показники комплексної силової вправи в групі 3 високим рівнем БР підвищувалися на $62,2 \%(\mathrm{P}<0,05)$, порівняно із значенням в групі 3 низьким рівнем БР. Також встановлено достовірне зростання показників у стрибках в довжину з місця в групі з високим рівнем БР на 28,8\% (P<0,05) у порівнянні із значенням групи 3 низьким рівнем БР. Одночасно відбувалося і підвищення гнучкості на 53,4\% $(\mathrm{P}<0,05)$ в групі з високим рівнем БР. Показники підтягування з вису зростали у 2,9 рази в групі з високим рівнем БР, порівняно із результатами групи з низьким рівнем БР.

Однак, поряд із істотним приростом названих показників в групі з високим рівнем БР виявлено зниження показників в бігу на 100 і 1000 м та під час човникового бігу 4x9 м по відношенню до значення групи з низьким рівнем БР.

Таблиия 4

Фізична підготовленість учнів ліщею з різним рівнем біологічного розвитку

\begin{tabular}{|c|c|c|c|c|c|}
\hline \multirow[t]{3}{*}{ Показник } & \multicolumn{5}{|c|}{ Рівень біологічного розвитку } \\
\hline & Низький & $\begin{array}{c}\text { Нижче } \\
\text { середнього }\end{array}$ & Середній & \begin{tabular}{c|} 
Вище \\
середнього
\end{tabular} & Високий \\
\hline & $n=65$ & $\mathrm{n}=73$ & $\mathrm{n}=96$ & $\mathrm{n}=75$ & $\mathrm{n}=23$ \\
\hline КСВ за 1 хв. & $37,34 \pm 1,26$ & $38,03 \pm 1,30$ & $43,47 \pm 1,25^{*}$ & $53,47 \pm 1,02 * \Delta$ & $60,57 \pm 1,35 * \Delta \bullet$ \\
\hline $100 \mathrm{M}, \mathrm{c}$ & $10,22 \pm 0,22$ & $10,98 \pm 0,31^{*}$ & $12,23 \pm 0,34 *$ & $12,57 \pm 0,28 *$ & $13,12 \pm 0,23 * \Delta$ \\
\hline $\begin{array}{l}\text { Стрибок } 3 \\
\text { місця, см } \\
\end{array}$ & $188,20 \pm 2,64$ & $187,33 \pm 3,40$ & $207,57 \pm 2,08 *$ & $223,57 \pm 1,82 * \Delta$ & $242,39 \pm 3,24 * \Delta \bullet$ \\
\hline $\begin{array}{l}\text { Човниковий } \\
\text { біг, } 4 \times 9\end{array}$ & $11,27 \pm 0,40$ & $10,59 \pm 0,17$ & $11,28 \pm 0,43$ & $17,92 \pm 0,98 * \Delta$ & $24,94 \pm 0,93 * \triangleleft \bullet \bullet$ \\
\hline Біг, 1000 м & $5,18 \pm 0,32$ & $6,20 \pm 0,30^{*}$ & $6,83 \pm 0,25^{*}$ & $6,49 \pm 0,41^{*}$ & $9,16 \pm 0,86^{*} \triangleleft \Delta \bullet$ \\
\hline $\begin{array}{l}\text { Нахил } \\
\text { тулуба } \\
\text { вперед, см }\end{array}$ & $9,58 \pm 0,78$ & $10,37 \pm 0,70$ & $11,07 \pm 0,67$ & $13,49 \pm 0,77 * \Delta$ & $14,70 \pm 1,15^{*} \triangleleft \Delta$ \\
\hline $\begin{array}{l}\text { Підтягування } \\
\text { у висі, разів }\end{array}$ & $5,78 \pm 0,58$ & $6,27 \pm 0,57$ & $10,80 \pm 0,47 *$ & $12,78 \pm 0,58 * \Delta$ & $16,96 \pm 1,05^{*} \bullet \bullet \bullet$ \\
\hline
\end{tabular}

Примітки: 1) Достовірні відмінності $(\mathrm{P}<0,05)$ позначено * - у порівнянні із показниками групи 3 низьким рівнем біологічного розвитку; - - п порівнянні із показниками групи 3 нижче середнього рівнем біологічного розвитку; $\Delta-$ у порівнянні із показниками групи з середнім рівнем біологічного розвитку; • - у порівнянні із показниками групи з вище середнього рівня біологічного розвитку.

Дискусія. Відомо, що період статевого дозрівання супроводжується збільшенням м'язової маси та м'язової сили $[4,14]$. Поряд з тим зростає напруга регуляторних механізмів, яка обумовлена дисбалансом роботи залоз внутрішньої секреції та нервових центрів. Фізичні вправи у відповідності до вікових особливостей організму здійснюють стимулюючий вплив на процеси фізичного розвитку лише у тому випадку, коли вони відповідають віковим, статевим та функціональним можливостям індивіда. Специфіка навчального процесу у ліцеях-інтернатах з посиленою фізичною підготовкою обумовлена не тільки великим обсягом фізичних навантажень, але і необхідністю досягнення високого рівня розвитку фізичних якостей $[3,7,8]$. Звідси, надзвичайно важливим $\epsilon$ дозування фізичних навантажень у відповідності до функціональних можливостей організму підлітків [6]. Однак у практиці широкого застосування набули підходи у дозуванні фізичних навантажень в залежності від рівня розвитку фізичних якостей. Але науковці все частіше вказують на важливість застосування диференційованих підходів у фізичній культурі з урахуванням соматометричних ознак фізичного розвитку [11] та 
біологічного віку [14]. Щодо урахування функціонального стану організму та рівня біологічного розвитку індивіда, то на це звертають увагу тільки поодинокі дослідники [5].

Відомо, що в процесі онтогенезу диференціація фізіологічних систем, а відтак i розвиток фізичних здібностей відбувається нерівномірно, тобто гетерохронно $[4,5]$. Це підтверджується отриманими нами даними, які відображають прогресуючий розвиток силових здібностей учнів із збільшенням рівня біологічного розвитку та зниженням показників швидкісних здібностей, витривалості і спритності. Вказана закономірність поєднується із зниженням функціональних резервів кардіореспіраторної системи та регуляторних систем організму. Урахування вказаних особливостей в процесі фізичної підготовки підлітків сприятиме зростанню ефективності занять фізичними і спортивними вправами і забезпечить належний розвиток як функціональних резервів, так i резистентності організму до впливу факторів довкілля.

Висновок. Підвищення рівня біологічного розвитку супроводжується зростанням розвитку силових та швидкісно-силових якостей, а також гнучкості. Натомість, у період інтенсивного статевого дозрівання, на фоні уповільнення процесів диференціації кардіореспіраторної системи і зростання напруги механізмів нейрогуморальної регуляції функцій організму, уповільнюється зростання аеробних можливостей (витривалості).

Розвиток фізичних здібностей та функціональних резервів фізіологічних систем відбувається гетерохронно, що обумовлено різними темпами росту організму та біологічного розвитку.

Урахування виявлених особливостей фізичного та функціонального стану організму підлітків з різним рівнем біологічного розвитку в процесі фізичної підготовки дозволить більш ефективно здійснювати дозування фізичних навантажень у підлітковому віці.

1. Агаджанян НА Федоров ЮИ Шеховцов В П Макарова ИИ Состояние кардиореспираторной системы и психологического статуса подростков суворовського училища в период адаптации к новым социально-средовым условиям. Экология человека. 2004; 4: 16-19.

2. Баженков СВ, Свідлов ЮІ, Бугрій ВС, Кормілець СВ. Н 32 Настанова з фізичної підготовки в кадетському корпусі та військових ліцеях: методичний посібник для вчителів військових ліцеїв. Суми; 2014. $160 \mathrm{c}$.

3. Балушка Л. Рівень фізичної підготовленості учнів ліцею 3 поглибленою військово-фізичною підготовкою. Молода спортивна наука України: зб. наук. праць з галузі фіз. виховання, спорту і здоров’я людини. 2014; 18(2): 3-6.

4. Глазирін I, Архипенко В, Глазиріна В, Мицкан Б. Особливості біологічного дозрівання учнівської та студентської молоді чоловічої статі визначеного за темпами статевого розвитку. Вісник Прикарпатського університету. Фізична культура. 2018; 29: 11-16.

5. Глазирін I, Глазиріна В. Диференційоване вдосконалення витривалості юнаків. Вісник Прикарпатського університету. Фізична культура. 2016; 23: 21-25.

6. Дугіна НГ, Мохова IВ, Борисова ЮЮ. Оцінка фізичного стану підлітків 13-14 років. Педагогіка, психологія, та медико-біологічні проблеми фізичного виховання і спорту. 2011; 1: 51-53.

7. І Ільницький I, Окопний А, Палатний А. Удосконалення фізичної підготовленості учнів ліцеїв 3 посиленою військово-фізичною підготовкою за допомого програм секційних занять з боксу. Фізична активність, здоров'я і спорт. 2017; 3(29): 14-23.

8. Ільницький I, Окопний А. Рівень фізичної підготовленості учнів ліцею 3 посиленою військово-фізичною підготовкою. Науковий часопис НПУ імені М.П. Драгоманова. Серія 15: Науково-педагогічні проблеми фізичної культури (Фізична культура і спорт) : зб. наук. пр. 2017; 9 (91) 17: 30-34.

9. Макарова Г.А. Практическое руководство для спортивных врачей. Ростов-на-Дону: Изд-во БАРО ПРЕСС, 2002. $800 \mathrm{c}$.

10. Мицкан БМ, Поташнюк IВ. Фізичний стан учнів старших класів гімназії. Педагогіка, психологія та медико-біологічні проблеми фізичного виховання і спорту. 2011; 5: 63-67.

11. Никитюк ДБ, Миннибаев ТШ, Клочкова СВ, Алексеева НТ, Тимошенко КТ. Роль антропометрического метода в оценке физического развития детей и подростков в норме и патологии. Журнал анатомии и гистопатологии. 2014; 3(3): 9-14. 
12. Петришин Ю, Дацків П. Показники рівня фізичної підготовленості учнів середнього шкільного віку. Спортивна наука України [Інтернет]. 2014 [цитовано 2018 Груд. 27]; 1(59): 3-7. URL: http://sportscience.ldufk.edu.ua/index.php/snu/article/view/205.

13. Руденко ВМ. Математична статистика: навч. посіб. К.: Центр учбової літератури; 2012. 304 с.

14. Сітовський АМ. Диференційований підхід у фізичному вихованні підлітків з різними темпами біологічного розвитку (на прикладі школярів 7-х класів) : автореф. ... канд. наук з фізичного виховання і спорту : спец. 24.00 .02 «Фізична культура, фізичне виховання різних груп населення» / А. М. Сітовський. Львів, 2008. 20 с.

15. Сологуб О. Особливості фізичного стану підлітків в умовах сьогодення. Гірська школа Українських Карпат. 2017; 16: 121-24.

16. Щирба В. Оцінка фізичної підготовленості учнів ліцеїв із посиленою військово-фізичною підготовкою. Фіз. виховання, спорт і культура здоров'я у сучасному суспільстві. 2016 ; 4 (36): 53-59.

17. New WHO Child Growth Standards, 2007. URL: https://www.who.int/growthref/hfa_boys_z_ WHO2007_exp.txt.

\section{References}

1. Agadzhanyan NA Fedorov YI Shekhovtsov VP Makarova II The state of the cardiorespiratory system and the psychological status of adolescents in the Suvorov school during the period of adaptation to new social and environmental conditions. Human Ecology. 2004; 4: 16-19.

2. Bazhenkov YeV, Svidlov YuI, Buhrii VS, Kormilets SV. N 32 Nastanova z fizychnoi pidhotovky v kadetskomu korpusi ta viiskovykh litseiakh. Metodychnyi posibnyk dlia vchyteliv viiskovykh litseiv. Sumy; 2014. $160 \mathrm{~s}$

3. Balushka L. Riven fizychnoi pidhotovlenosti uchniv litseiu z pohlyblenoiu viiskovo-fizychnoiu pidhotovkoiu. Moloda sportyvna nauka Ukrainy:zb. nauk. prats z haluzi fiz. vykhovannia, sportu i zdorovia liudyny. 2014; 18(2): 3-6.

4. Hlazyrin I, Arkhypenko V, Hlazyrina V, Mytskan B. Osoblyvosti biolohichnoho dozrivannia uchnivskoi ta studentskoi molodi cholovichoi stati vyznachenoho za tempamy statevoho rozvytku. Visnyk Prykarpatskoho universytetu. Fizychna kultura. 2018; 29: 11-16.

5. Hlazyrin I, Hlazyrina V. Dyferentsiiovane vdoskonalennia vytryvalosti yunakiv. Visnyk Prykarpatskoho universytetu. Fizychna kultura. 2016; 23: 21-25.

6. Duhina NH, Mokhova IV, Borysova YuIu. Otsinka fizychnoho stanu pidlitkiv 13-14 rokiv. Pedahohika, psykholohiia, ta medyko-biolohichni problemy fizychnoho vykhovannia i sportu. 2011; 1: 51-53.

7. Ilnytskyi I, Okopnyi A, Palatnyi A. Udoskonalennia fizychnoi pidhotovlenosti uchniv litseiv z posylenoiu viiskovo-fizychnoiu pidhotovkoiu za dopomoho prohram sektsiinykh zaniat z boksu. Fizychna aktyvnist, zdorovia i sport. 2017; 3(29): 14-23.

8. Ilnytskyi I, Okopnyi A. Riven fizychnoi pidhotovlenosti uchniv litseiu z posylenoiu viiskovo-fizychnoiu pidhotovkoiu. Naukovyi chasopys NPU imeni M.P. Drahomanova. Seriia 15: Naukovo-pedahohichni problemy fizychnoi kultury (Fizychna kultura i sport) : zb. nauk. pr. 2017; 9 (91) 17: 30-34.

9. Makarova GA. A practical guide for sports doctors. Rostov-on-Don: Publishing house BARO - PRESS, 2002. $800 \mathrm{p}$.

10. Mytskan BM, Potashniuk IV. Fizychnyi stan uchniv starshykh klasiv himnazii. Pedahohika, psykholohiia ta medyko-biolohichni problemy fizychnoho vykhovannia i sportu. 2011; 5: 63-67.

11. Nikityuk DB, Minnibaev TSh, Klochkova SV, Alekseeva NT, Timoshenko KT. Rol antropometricheskogo metoda $\mathrm{v}$ otsenke fizicheskogo razvitiya detey i podrostkov $\mathrm{v}$ norme $\mathrm{i}$ patologii. Zhurnal anatomii $\mathrm{i}$ gistopatologii. 2014; 3(3): 9-14.

12. Petryshyn Yu, Datskiv P. Pokaznyky rivnia fizychnoi pidhotovlenosti uchniv serednoho shkilnoho viku. Sportyvna nauka Ukrainy [Internet]. 2014 [tsytovano 2018 Hrud. 27]; 1(59): 3-7. URL: http://sportscience. ldufk.edu.ua/index.php/snu/article/view/205.

13. Rudenko VM. Matematychna statystyka. Navch. posib. K.: Tsentr uchbovoi literatury; 2012. $304 \mathrm{~s}$.

14. Sitovskyi AM. Dyferentsiiovanyi pidkhid u fizychnomu vykhovanni pidlitkiv z riznymy tempamy biolohichnoho rozvytku (na prykladi shkoliariv 7-kh klasiv): avtoref. ... kand. nauk z fizychnoho vykhovannia i sportu. 24.00.02 «Fizychna kultura, fizychne vykhovannia riznykh hrup naselennia». Lviv, 2008. $20 \mathrm{~s}$.

15. Solohub O. Osoblyvosti fizychnoho stanu pidlitkiv v umovakh sohodennia. Hirska shkola Ukrainskykh Karpat. 2017; 16: 121-24.

16. Shchyrba V. Otsinka fizychnoi pidhotovlenosti uchniv litseiv iz posylenoiu viiskovo-fizychnoiu pidhotovkoiu. Fiz. vykhovannia, sport i kultura zdorovia u suchasnomu suspilstvi. $2016 ; 4$ (36): 53-59.

17. New WHO Child Growth Standards, 2007. URL: https://www.who.int/growthref/hfa_boys_z WHO2007_exp.txt 


\section{Цитування на цю статтю:}

Корсак ОМ, Лемак ОЙ, Султанова ІД, Іванишин IM. Морфо-функціональний стан підлітків 3 різним рівнем біологічного розвитку. Вісник Прикарпатського університету. Серія: Фізична культура. 2020 Листоп 24; $36: 26-38$

\begin{tabular}{|c|c|}
\hline Відомості про автора: & Information about the author: \\
\hline $\begin{array}{l}\text { Корсак Олександр Михайлович-аспірант, ДВНЗ } \\
\text { “Прикарпатський національний університет імені } \\
\text { Василя Стефаника” (Івано-Франківськ, Україна) }\end{array}$ & $\begin{array}{l}\text { Korsak Oleksandr Mykhailovych - post-graduate stu- } \\
\text { dent, Vasyl Stefanyk Precarpathian National Univer- } \\
\text { sity (Ivano-Frankivsk, Ukraine) }\end{array}$ \\
\hline \multicolumn{2}{|l|}{ https://orcid.org/0000-0003-1787-0267 } \\
\hline $\begin{array}{l}\text { Лемак Олександр Йосипович - аспірант, ДВНЗ } \\
\text { “Прикарпатський національний університет імені } \\
\text { Василя Стефаника" (Івано-Франківськ, Україна) }\end{array}$ & $\begin{array}{l}\text { Lemak Oleksandr Yosypovych - post-graduate stu- } \\
\text { dent, Vasyl Stefanyk Precarpathian National Univer- } \\
\text { sity (Ivano-Frankivsk, Ukraine) }\end{array}$ \\
\hline \multicolumn{2}{|l|}{ https://orcid.org/0000-0002-5032-1959 } \\
\hline $\begin{array}{l}\text { Султанова Ірина Дмитрівна - кандидат біоло- } \\
\text { гічних наук, доцент, ДВНЗ “Прикарпатський на- } \\
\text { ціональний університет імені Василя Стефаника" } \\
\text { (Івано-Франківськ, Україна) }\end{array}$ & $\begin{array}{l}\text { Sultanova Iryna Dmytrivna - Candidate of Science } \\
\text { (Biology), Associate Professor (Ph. D.), Vasyl Stefa- } \\
\text { nyk Precarpathian National University (Ivano- } \\
\text { Frankivsk, Ukraine) }\end{array}$ \\
\hline \multicolumn{2}{|l|}{$\begin{array}{l}\text { e-mail: irynasultanova@gmail.com } \\
\text { https://orcid.org/00-0003-2298-359X }\end{array}$} \\
\hline $\begin{array}{l}\text { Іванииин Ірина Мирославівна-кандидат хіміч- } \\
\text { них наук, доцент, ДВНЗ “Прикарпатський націо- } \\
\text { нальний університет імені Василя Стефаника" } \\
\text { (Івано-Франківськ, Україна) }\end{array}$ & $\begin{array}{l}\text { Ivanyshyn Iryna Myroslavivna - Candidate of Scien- } \\
\text { ce (Chemistry), Associate Professor (Ph. D.), Vasyl } \\
\text { Stefanyk Precarpathian National University (Ivano- } \\
\text { Frankivsk, Ukraine) }\end{array}$ \\
\hline $\begin{array}{l}\text { e-mail: Iraivan68@gmail.com } \\
\text { https://orcid.org/0000-0003-1765-8311 }\end{array}$ & \\
\hline
\end{tabular}

УДК 376: 612.885/86

Свген Миценко doi: 10.15330/fcult.36.38-45

\section{ПРИДАТНІСТЬ ЗАСОБІВ ОЦІНКИ РУХОВОЇ ФУНКЦІЇ ДЛЯ МОНІТОРИНГУ СТАНУ ДІТЕЙ 3 РОЗЛАДАМИ СПЕКТРУ АУТИЗМУ}

Мета. Дослідження спрямоване на перевірку придатності тестів, як інструментів оцінки рухової функиії дітей з розладами спектру аутизму. Представляє аналіз засобів і методів, які дозволяють оцінити рухову сферу людини і можуть бути застосовані до дітей з розладами спектру аутизму. Методи. Було відібрано шістнадиять хлопців з розладами спектру аутизму, віком від 7 до 11 років. Також для них були підібрані рухові тести з урахуванням теорії Миколи Берштейна про координацію та регуляцію рухів. А саме: теппінг тест, проба Ромберга, спеціально регламентовані стрибки/ходьба по платформах, ходьба на задану відстань, відтворення кута підйому передпліччя, ліплення, перекати в сторону, стрибок на точність, ходьба над лавками, метання кульки в ціль, монтаж-демонтаж заклепок, перебудова стереотипу письма. Дві групи рухових тестів було порівняно: одна група тих, щзо були розроблені та використовувалися раніше іншими дослідниками для здорових людей та інша група тестів, щцо були розроблені нами для роботи з дітьми з розладами спектру аутизму. Метою порівняння було оцінити різницю в тому наскільки иі тести є придатними для виконання дітьми з розладами спектру аутизму, та на основі отриманих даних обтрунтувати доиільність їх застосування. Результати. Отримані результати порівняння показали значну різницю між двома групами рухових тестів 8 тому наскільки рухові завдання, що лежать в їх основі доступні для розуміння дітей з розладами спектру аутизму. Відсоток засвоєних досліджуваними інструкцій з виконання рухових завдань, суттєво різниться для першої та другої групи тестів $(P<0.05)$. А саме виявлено, щзо друга група моторних тестів є для них більш зрозумілою ніж перша. Висновок. 3 наведеного можна зробити висновок, шо запропоновані нами тести більш ефективні для оцінки рухової функції дітей з розладами спектру аутизму ніж ті, щчо застосовувались раніше іншими дослідниками для здорових людей.

Ключові слова: оцінка, розлади спектру аутизму, діти, рухова функиія. 